\title{
AN ANALYSIS OF GRAMMATICAL ERRORS MADE BY 3rd-YEAR THAI BUSINESS ENGLISH UNDERGRADUATES WHEN SPONTANEOUSLY WRITING NARRATIVE AND DESCRIPTIVE PARAGRAPHS
}

\author{
Mr Anthony Goldsmith ${ }^{*} 凹$ iD , Ms Pattanan Sujaritjan 2 iD \\ ${ }^{* 1,2}$ Lecturer of English, Business English Department, Ubon Ratchathani Rajabhat University, \\ Thailand
}

DOI: https://doi.org/10.29121/granthaalayah.v8.i8.2020.920

Article Type: Research Article

Article Citation: Mr Anthony Goldsmith, and Ms Pattanan Sujaritjan. (2020). AN ANALYSIS OF GRAMMATICAL ERRORS MADE BY

3rd-YEAR THAI BUSINESS ENGLISH UNDERGRADUATES WHEN SPONTANEOUSLY WRITING NARRATIVE AND DESCRIPTIVE PARAGRAPHS. International Journal of Research -GRANTHAALAYAH, 8(8), 75-95.

https://doi.org/10.29121/granthaa layah.v8.i8.2020.920

Received Date: 28 July 2020

Accepted Date: 21 August 2020

Keywords:

Spontaneous Paragraph Writing Written Grammar Errors

\section{ABSTRACT}

This research reviews the grammatical errors written by sixty-eight, 3rd-year, Thai, Business English undergraduates when spontaneously writing narrative and descriptive paragraphs. The data was analysed using percentages, mean scores, standard deviation scores, and t-test p-values. The research results show that the students wrote 837 sentences with a mean score of 6.154 sentences per paragraph. 86 were written correctly and 751 were written incorrectly with 2131 grammar errors. The grammatically correct written sentences were all simple sentences. The most frequent errors identified were 227 verb (V) errors $(10.652 \%$ of identified errors). There is a mean of 31.338 errors per participant (SD 9.957), a mean of 15.669 errors per paragraph, and a mean of 2.837 errors for each incorrectly written sentence. The female participants wrote a mean score of 12.685 sentences, which is $16.84 \%$ more than the males who wrote a mean of 10.857 sentences. Three error types by gender showed a high level of significance. These were noun errors with a t-test $p$-value of 0.012 , punctuation errors with a t-test p-value of 0.037 , and conjunction errors with a t-test p-value of 0.081 . The female students made a significantly higher number of errors in these three error groups.

\section{INTRODUCTION}

English has developed into the most internationally spoken language (Foley [1], 2006). An ever-increasing number of people are now learning English as a second (ESL) or foreign language (EFL) (Block [2], 2002; Crystal [3], 2003; Holliday [4], 2005; Nunan [5], 2001). The important benefits of learning English in the global market are: (a) improving global understanding, (b) increasing potential employment, (c) improving chances for accessing higher education institutions, (d) increasing options for studying abroad, and (e) improving the understanding of alternative cultures.

The growing demand for English language education and the growing need for well-qualified English language teachers have become increasingly important in Thailand where people often find it difficult to write in their native language and this is made worse when people attempt to write in a foreign language. The interference of their native language over their attempts to acquire and use a foreign language is well documented. This is especially so for

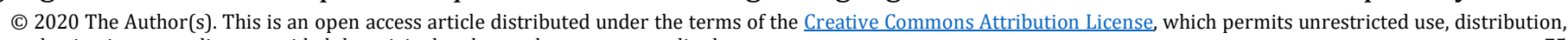
and reproduction in any medium, provided the original author and source are credited. 
An Analysis of Grammatical Errors Made By 3rd-Year Thai Business English Undergraduates When Spontaneously Writing Narrative and Descriptive Paragraphs

English Foreign Language (EFL) students, as documented by many researchers including Lado [6] (1964), Jiang [7] (1995), Yu [8] (1996), Mori [9] (1998), Jarvis [10] (2000), Collins [11] (2002), Chen and Huang [12] (2003), and Goldsmith \& Dennis [13] (2016).

STATEMENT OF THE PROBLEM: Writing short English paragraphs is a challenge for Thai students, particularly as English and Thai are structurally so different. This issue is compounded by the persistent use of the 'grammar/translation model' that is entrenched in Thai EFL education. When compared to international English proficiency, Thailand is somewhat lacking (Goldsmith, \& Dennis, 2016). Wachs [14], (1993) indicates that students who memorize English vocabulary and grammar rules seldom use the knowledge in any practical way. Most of the students are constantly translating words, phrases, and sentences from Thai to English, which repeatedly results in structural errors.

Competent teachers are required to find pragmatic teaching methods to help their students improve their writing skills. This requires a deeper understanding of what type of errors the students make as well as a review of the teachers' competency. Whilst a review of teacher competency is beyond the parameters of this research, it should be remembered that the Thai Ministry of Education's research found only 6 out of 43,000 Thai English teachers that were fluent in English (Kantabutra [15] 2015). Teachers need to help the students become more proficient writers and at the same time, work to eliminate their own as well as their students' writing errors.

There is little doubt that writing English into legible text is very difficult for an EFL student (Richards \& Renandya [16], 2002). It is very important to review the writing errors the Thai students make, as writing English competently is beneficial to their development and the development of Thai international commerce.

Writing English involves a plethora of choices regarding a variety of writing skill levels. These choices include punctuation, vocabulary, word choice, and grammatical structure as well as deciding upon content, and organisation of the written text (Richards \& Renandya 2002).

Both Noon-Ura [17] (2013) and Wiriyachitra [18] (2013) highlight the contemporary failings of the current English education in Thailand. We need to discover precisely why Thai students entering university are unable to write English after 12 years of classroom instruction. Even simple sentences are difficult for most students despite prolonged grammar and translation drilling. It is clear that successful EFL learning is highly dependent upon effective teaching (Dixon et al. [19], 2012). Utilising an appropriate teaching methodology is therefore very important. There are many methodological theories that are used to justify instruction methods and all have their advocates and have varying levels of efficacy. The use of the Grammar-Translation Approach, in a modified form continues to be widely used in Thailand. The result of using this method creates frustration for students and makes few demands on teachers (Goldsmith \& Dennis 2016). Though it may be true to say that the Grammar-Translation Method is still practiced in Thailand and Japan, it has no international academic champions. It is a method unsupported by a theory. There is no literature that offers a rationale or justification for using the grammartranslation method. There is also no literature that attempts to relate it to issues in linguistics, psychology, or educational theory (Fitriyanti and Soraya [20], 2011). The Thai EFL students in Goldsmith's (2016) study expressed great dissatisfaction about their experiences of the grammar translation method.

Most students studying English at UBRU find it difficult to write paragraphs and essays without various errors. This can also true for the Thai teaching staff (Goldsmith 2016). English-writing teachers must anticipate common errors that their students make. Additional error types may also be exposed by analysing the students' written narrative and descriptive paragraphs.

In spite of the fact that Thai EFL undergraduates have studied English for more than twelve years, their vocabulary repertoire and syntactic ability is severely lacking. It is not unreasonable to expect them to have a wide vocabulary, and have an ability to use English grammar with reasonable success. This is the case in other East Asian countries where the EFL students have demonstrated higher proficiency levels (EF EPI [21], 2019). Yet, most of the Thai students are still unable to write a paragraph using adequate basic structures of the English language they have previously been drilled on and supposedly had learnt.

The teachers must encourage their students to listen, speak, read, and then write. The only way to improve writing skills is to write, but this has to follow the development of the other English language skills. If students feel they are lacking at writing English, they will avoid writing. This is problematic in Thailand where students will not write as they feel that making mistakes will lead to a loss of face (Goldsmith 2016). Therefore, they do not practice and they do not improve. 
Purpose of The Study: The purpose of this study is to review and clearly identify the common errors that the Business English (BE) undergraduate students at UBRU make when writing narrative and descriptive paragraphs. This is so that the teachers that insist on continuing to use the grammar translation model are forewarned about the most common writing errors their students will make so that they can focus their attention on these most problematic areas. This will provide a more pragmatic approach to teaching grammar.

The Scope And Aim of The Study: The aim of the study is the development of a clear understanding of the type and extent of writing errors made in order to provide contemporary information that can be used to enable English writing and grammar teachers to focus their time and attention where it is needed in a pragmatic way. This will lead to a rubric of grammar errors that can be used by any EFL teachers Thailand as a basis for the students' grammar development.

\section{Research Questions:}

1) What type of errors do the sample students make when writing English narrative and descriptive paragraphs?

2) How frequently do the sample students make the various types of errors?

3) What are the most common types of written English errors made by the BE students?

4) Are there any differences in the type and frequency of errors written by male and female students?

Limitations of The Study: Generalisations of this study and the results are limited to the population of $3^{\text {rd-year }}$ EFL BE students studying within Ubon Ratchathani Rajabhat University. Comparative research analysis is complicated by the plethora of analysis taxonomies used by other researchers

Significance of The Study: The understanding of the common errors made and the subsequent educational rubric can be used in schools and within the Rajabhat university system to improve focussed education that is pragmatic.

Mistakes Vs Errors: A mistake occurs when a person fails to use a system that is previously known to them, correctly (Brown [22] 1994). Mistakes happen frequently when writing. Even professional writers need to check and edit their work to rectify written errors. The individual making the mistake is able to recognise that they have made the mistake and is able to rectify their mistake. An error occurs when a person unknowingly deviates from the grammar used by a competent native speaker (Brown 1994). Because the error is unknown to the person making the error, they are unable to correct it without guidance. A mistake can be self-corrected, whereas, an error cannot.

Grammar errors are continuously repeated by EFL learners until the teacher intervenes. It is up to the teacher to identify the errors that their students make (Gass \& Selinker [23], 1994). Error are systematic syntactic deviations where learners have not learnt something and fail to get it right (Norrish [24] 1983). This implies that EFL learners make consistent and persistent errors because they have not yet learnt how to use the language correctly.

For educationalists, errors must be taken seriously. Teachers need to be able to identify EFL student writing errors and know how to help the student rectify them. Making errors is a normal part of learning a foreign language. EFL writing errors indicate that learning is taking place and inform the teacher how far the learner has progressed. Student errors provide feedback for the teachers, and they can be used to focus educational directions. Where the errors are common, the feedback should help with the development of pragmatic curricula.

Errors Are Not All Equal: EFL students' errors are important fields of study for many teachers. These errors indicate the progressive advancement of the learners towards their goals, and highlights what the learners have yet to learn. Researching these errors also provides evidence about how language is acquired and what methods the students use to aid their development (Corder [25],1967). There is clear evidence that emphasising upon the errors made helps to improve the learners' grammatical accuracy (White and Arndt [26], 1991; Carroll and Swain [27], 1993). Students need to recognise their written errors to recognise and understand how their errors were made. To do this, the teachers must also be able to recognise the errors and be able to help the students correct these errors.

Types of Errors: Researchers often distinguish between competence errors and performance errors. Competence errors reflect inadequate learning, which is more serious. Performance errors are made by learners when they are tired or when they hurry. Burt and Kiparsky [28] (1974) define errors as local and global. Local errors do not hinder communication. Global errors are considered more serious because they interfere with 
communication and disrupt the meaning. Noun and verb errors, articles, prepositions, and auxiliary verb errors are considered local errors, as the meaning is not lost. Whereas severe word order errors or wrong words are considered global errors as, the meaning is lost.

Kuntjara \& Limengka [29] (2013) divided errors into 5 types. They are:

1) Omission - which is the removal of a necessary part of a sentence.

2) Addition - which is the addition of unnecessary items in a sentence.

3) Misformation - which is any wrong form of certain morphemes or structures.

4) Misordering - which is any incorrect placement of certain morphemes in sentences.

5) Blends - which is where two or more morphemes that have the same function appear in a sentence.

Error Analysis: Error Analysis (EA) is the study of language structurers that deviate from the target language accepted structure. These deviations (errors) occur during learners' language education. The analysis of these student errors helps identify the types and sources of errors, which can lead to accurate, focussed, and pragmatic teaching. This will ultimately help to reduce the errors made by students.

Identifying EFL students' errors is very important for their teachers and is necessary if they want to help their students correct their errors. Identification of the EFL students' errors helps the teachers to be effective. Dulay, Burt and Krashen [30] (1982) state that the analysis of errors is the method to analyse errors made by EFL and ESL learners when they learn a language

This research aims to inform teachers about the grammar errors that require corrective work. This is so that teaching grammar is pragmatic and focussed on the common errors that the majority of the EFL students make when writing.

The primary aim of error analysis is to help teachers accurately assess what corrective work is required for EFL students in order to help them prevent making the common errors identified (Lim [31] 1976). Corder (1967) stated that errors are important in and of themselves. Making errors is crucial for EFL students, and should be considered as a mechanism that they can use as they learn. Corder, goes on to state that systematically analysing students written errors enables teachers to define areas that need additional focussed teaching.

Process for Error Analysis: Sridhar [32], (1980) suggested six steps for error analysis:

1) Collection of data from a 'free' student' composition on a given theme.

2) Identification of errors, and labelling the nature of the deviation

3) Classification into error types such as errors of agreement, articles, verb forms, etc.

4) Statement of relative frequency of error types

5) Identification of the areas of difficulty in the target language

6) Therapy, including remedial drills and lessons

Gass \& Selinker (1994) identified six very similar steps in the process of error analysis.

The research shows that EFL students make a plethora of errors when writing English. Most studies that focus on the causes and sources of errors and error analysis concluded that mother-tongue interference is the main responsible factor for students' written errors.

Owe-Ewie and Williams [33] (2017) studied $1502^{\text {nd }}$-year students English writing. They used content analysis and found that tense errors were the most frequent followed by verb agreement errors.

Hamzah [34] (2012) conducted a content analysis of 20 written texts written by undergraduate, Indonesian students. The errors were categorised, tabulated, and classified into the following categories: word choice the most frequently found error), spelling, article, preposition, pronoun agreement, relative clauses, pronoun deletion, word order, verb group - productions of verb, distribution of verb and tense, plurality, mechanics, possessive, and copula omission. These categories were first described and suggested for error analysis by Etherton [35], A (1977).

Singh et al [36]. (2017), reviewed one hundred and forty-four ESL diploma students' written essays using content analysis. They found that subject-verb agreement and tenses were the most common type of errors made. Another common error found was in the students' construction of complex sentences where they failed to include essential and nonessential clauses.

The primary difficulty identified when attempting to compare the various pieces of research is that they each use differing analytical methods and gramma error taxonomies. This makes it difficult when attempting to identify a definitive preferred way of categorising the errors that EFL writers make. 
There have been many studies over the last 12 years that have focussed upon the written grammar errors made by Thai EFL students. Bennui [37] (2008) reviewed the errors made by 28 third-year English minor students at Thaksin University when writing paragraphs. He identified the extent of L1 interference in Thai writing that indicated the issue of literal translation, which caused lexical issues. He also identified structural issues, including word order, subject-verb agreement, and noun determiners indicating features of L1 syntactic interference. อรษา ร้อยแก้ว [38] (2008), on the other hand, reviewed forty-five English job application letters written by second-year Faculty of Agricultural Technology students. He identified only 114 errors. However, the students were prepared prior to the data collection. The researcher taught them a business letter format word by word. They learnt how to write job application letters. Then each student wrote a job application letter individually using the template, and it is this preparation that may have led to such a low number of written errors being identified. The errors identified, in order of frequency, were punctuation marks, verb tense consistency, run-on sentences, sentence fragmentation, pronoun, word order, preposition, "in part of speech", and the article. The document presented by อรษา ร้อยแก้ว (2008) was itself, written with a plethora of English grammar errors, which far exceeded the number of errors made by the sample student group it reviewed. Therefore, it could also be the inability of the author to identify personally written errors that led to the low number of identified errors in the sample letters.

Kaewnuch \& Boonsue [39] (2012) reviewed 26 fourth-year English major students analysis of first-year students written errors, at Srinakharinwirot University. The sample group were each given four paragraphs "riddled with errors". The most frequent errors identified were determiner errors, tense errors, word form errors, punctuation errors, subject-verb agreement errors, and verb form errors. The written paragraphs were also checked by the researchers who attained similar results to the fourth-year students.

Sukasame [40], et al., (2013) studied grammatical tense errors of 31 Matthayom Suksa four students at the Demonstration School of KhonKaen University (Suksasart), whilst learning English tense structures. The results showed the student's errors were found in twenty-two grammar rules in seven tenses. They were past perfect tense errors (87.1\%), past simple tense errors (74.2\%), present perfect tense errors $(67.4 \%)$, past continuous tense errors (54.8\%), present simple errors (48.4\%), future simple tense errors (41.7\%), and present continuous tense errors (32.3\%). "It was found that Thai students have problems of tense selection."

Watcharapunyaw-ong \& Ushaha's [41] (2013) research focussed on the grammar errors written by $402^{\text {nd }}-$ year Thai student in 120 paragraphs. The students each wrote a narrative, descriptive, and compare/contrast paragraph. The results revealed that the narrative paragraphs showed verb tense, word choice, sentence structure, preposition, and modal/auxiliary as the five most common errors. Whereas, in the description and compare/contrast paragraphs, the five most frequent errors were article errors, sentence structure errors, word choice errors, singular/plural form errors, and subject-verb agreement errors. However, Tiensawangchai [42] (2014) looked at the types of grammar errors written by twenty-six Thai EFL students at the Language Institute, Thammasat University when writing business English. Each student wrote eight business documents that were analysed. The study attempted to classify the errors using James [43] (1998) Error Analysis Model. The most-frequent grammar errors found fell into ten categories. They were subject-verb agreement (highest), sentence fragments, noun plurals, noun singular, tenses, spelling errors, active-passive voice, misselection of the article and comma splices, infinitive and noun morphology errors, and gerunds (lowest). This is similar to Nonkukhetkhong [44] (2013), who investigated grammar errors made by first year English major undergraduate students at Udon Thani Rajabhat University. The errors identified were verbs errors, nouns errors, possessive case errors, article errors, preposition errors, adjective errors, adverb errors, sentence structure errors, ordering errors, coordination/subordination errors, capitalisation errors, spelling errors, punctuations errors, word selection errors, word formation errors, ambiguous communication errors, and miscommunication errors.

Lush [45] (2002) reviewed the writing errors of third year undergraduate Thai students from Thammasart University, and revealed that the grammatical errors in essay writing fell into ten categories, which were misuse of articles, singular/plural nouns, present/past simple interchanged, prepositions, subject-verb agreement, incorrect tenses, word order, be/have interchanged, have/be interchanged and sentence fragmentation.

Thep-Ackrapong [46] (2015) and Goldsmith [47] (2015b, 2016) focussed their reviews on the personal experiences of teaching English in Thailand. Goldsmith (2015b, 2016) highlighted the difficulties experienced by Thai EFL undergraduate students at Ubon Ratchathani Rajabhat University. Thep-Ackrapong (2015) wrote about spoken English errors and identified subject-verb agreement, topic-comment structure, relative clause, and subordination grammar errors. Boonyarattanasoontorn [48] (2017) wrote about the difficulties that Thai students 
have writing English and indicated that the 157 undergraduate students reviewed clearly stated that grammar was their most problematic skill.

Khumphee \& Yodkamlue [49] (2017) reviewed 83 essays written by English major undergraduates studying at Nakhon Ratchasima Rajabhat University. They identified 4909 errors in the students' essays, which the researchers categorised into 26 types. The five most common error types they found were punctuation errors (17.15\%), noun errors (15.81\%), preposition errors (11.75\%), verb errors $(8.23 \%)$, and article errors (5.95\%). They found errors in 88.91\% of the written sentences. Whereas, Sermsook et al [50]., (2017) looked at 104 pieces of writing written by $242^{\text {nd }}$-year English major students in a Thai university. They focussed on sentences and identified the most frequent errors were punctuation, then articles, subject-verb agreement, spelling, capitalization, and fragment, respectively. They went on to say that interlingual and intralingual interference, limited knowledge of English grammar and vocabulary, and carelessness of the students were the major sources of the written errors. They also state that using Error Analysis will improve their students' writing ability.

It is clear that there is a great deal of research about EFL writing errors of students has been conducted by many scholars. It remains topical because of the persistence of error making. The Nation Thailand ${ }^{51}$ (2015) state succinctly that "Thailand is wasting money on language education if the curriculum smothers the joy of learning, and that Thai students are seemingly unable to improve their English-language skills. First, we must change the way English is taught. The daunting grammar lessons that dominate the English curriculum in Thai schools have been shown to be of less use than focusing on the rudiments of conversation. Students should be learning with their ears, gradually absorbing the subtleties of the language, just as they did in learning to speak their native language as infants. They should be encouraged to listen and then speak English without having to worry about grammatical errors. Grammar can come later, once the students feel more at ease with the language." This should then lead to progressive reading and finally writing. Both Noon-Ura (2013) and Wiriyachitra (2013) highlight the contemporary failings of the current English education practice in Thailand and clearly identify a need for change. Thai Ministry of Education's research that found only 6 out of 43,000 Thai English teachers were fluent in English (Kantabutra 2015). It is therefore not surprising that students find it so difficult to write English correctly when many of their teachers demonstrate the same difficulties.

\section{METHODOLOGY}

\section{Participants}

The participants in this study are Thai, $3^{\text {rd }}$-year, Business English major, undergraduate students who enrolled in the Critical Reading and Writing module (1741243) at Ubon Ratchathani Rajabhat University. They are a purposive convenience sample of sixty-eight students that was determined by the number of students that attended class on the first day of the module. Of the sixty-eight participant students, fifty-four were female and fourteen were male. All of the participants were between twenty and twenty-three years of age. They had all been studying English for at least 12 years and they all had experience of learning with a native English teacher at the university.

\section{Research Instruments}

There are three instruments used in this study including written exercises, a structural review of the sentences, and a combined error taxonomy using an adapted version of Na-grams (2005) and Watcharapunyaw-ong \& Usaha's (2013) error categories.

1) The written exercise comprised of two paragraphs entitled:

- Describe your bedroom

- Write about your first day at the university

2) A structural review of simple, compound, or complex sentence types was made.

3) A 23-error category taxonomy based upon those used by Na-grams (2005) and Watcharapunyaw-ong \& Usaha (2013) and then adapted for this research to identify and categorise the grammar errors made (Appendix A). Watcharapunyawong's (2013) analysis using Error Analysis (EA) revealed that the first language interference errors fell into 16 categories. 


\section{Data Collection}

The participants were asked to write the two paragraphs and were informed that the exercise was part of a review to assess their writing ability without preparation, as this was considered a true reflection of their English writing competency. The participants were given one hour to plan and write their two paragraphs. The two written paragraphs were incorporated into the teaching time on the students' first day back from their holiday break. The data was collected during the second semester of the academic year of 2562-2563. The researchers collected the data.

Permission for using the data for research purposes was gained and each participant was given a free choice about having their paragraphs added to the data pool, which is a protocol required for social research. Participant anonymity was ensured as the respondents were told not to record their names on the data collection sheets. They were asked to record their gender.

\section{Data Analysis}

The written data was analysed using a simple content analysis.

Following the data collection, each of the participants' paragraphs was read by an experienced native English teacher employed in the Business English department at UBRU (Researcher with 30 years teaching experience).

All of the sentences were initially counted and categorised into three types, being 'simple' sentences, 'compound' sentences, and 'complex' sentences. All correctly and incorrectly written sentences were then counted. Where a sentence was structurally correct but written in the wrong tense, it was recorded as an incorrectly written sentence.

The sentences were then corrected with minimal change from their original form, which ensured that the students' word choices were retained where possible. Each of the required corrections was then analysed and categorised using the error taxonomy previously described.

The data was recorded in an excel database and the sentence and error totals were determined. The population mean scores $(\mu)$ and the standard deviation scores (std $(X)$ ) were also calculated. These figures were calculated for the entire participant population and for each gender group. A t-test p-value was then calculated between the two gender groups (samples) using the sample mean scores, the sample distribution scores and the sample standard deviation scores. This was done by using the 'Two sample t-test' calculator from the 'Select Statistical Services' website. This calculator tests whether samples from two independent populations (male and female) provide evidence that the populations have statistically different means. The test is designed to allow for differing population sizes and is appropriate for the analysis of the data collected in this research.

\section{RESULTS AND DISCUSSION}

This chapter is divided into two sections. Firstly, the results are explored in total and for each gender sample group. Student sentence examples are provided. This is followed by a discussion about the results and how the results relate to research conducted by other researchers.

Total Sentences: The total number of paragraphs written by the participants was 136 . The participant wrote 837 sentences, with a mean score of 6.154 sentences per written paragraph. The number of words in each sentence was not counted.

A mean score of 12.309 sentences were written by each student with a standard deviation of 5.931. The lowest number of sentences written by a student was two (one for each paragraph both written incorrectly) and the highest number of sentences written by a student was thirty-seven with thirty-three being correctly written.

The sentences were categorised into three sentence types and the distribution of the sentence types is shown in table 1.

Table 1: Sentence and Sentence Type Totals with Mean and Standard Deviation Scores for Individual Students

\begin{tabular}{|c|c|c|c|c|}
\hline & All Sentences & Simple & Compound & Complex \\
\hline Sentences & 837 & 589 & 109 & 140 \\
\hline Mean & 12.309 & 8.662 & 1.603 & 2.059 \\
\hline SD & 5.931 & 4.913 & 1.362 & 1.563 \\
\hline
\end{tabular}


The sentence correctness is absolute. That is, they were either correct or they were not. Out of the 837 total sentences written, 86 were written correctly (33 by one student) and 751 were written incorrectly with one of more errors. The mean and standard deviation score for the correct and incorrect (with at least one error) sentence categories are as follows in table 2 .

Table 2: Correctly and Incorrectly Written Sentences with Mean and Standard Deviation Scores for Individual Students

\begin{tabular}{|c|c|c|}
\hline & Correctly Written Sentences & Incorrectly Written Sentences \\
\hline Sentences & 86 & 751 \\
\hline Mean & 1.2647 & 11.0441 \\
\hline SD & 1.8171 & 5.3488 \\
\hline
\end{tabular}

It should be noted that the mean correctly written sentence by each student was only 1.265 and that no participant was able to write a grammatically correct compound or complex sentence. Thus, all of the participants' grammatically correct written sentences were simple sentences.

\section{Total Error Results}

The errors are divided into three groups and are reviewed in turn. First omission and addition errors are reviewed. This is followed by a brief review of the remaining collective errors, and finally each of the error groups is reviewed in ranked order of incidence starting with the most frequently identified error group.

\section{Total Omission and Addition Errors}

Omission and addition errors were counted separately from the other error groups. This was done because any error falling in one of these two groups was counted a second time in one of the other groups (depending what the addition or omission was). There were 760 omission and addition errors identified. 646 (85\%) were omission errors, which equates to a mean of 9.5 omission errors per participant (SD 5.64), a mean of 4.75 omission errors per paragraph, and a mean of 0.86 omission errors per incorrectly written sentence.

$114(15 \%)$ were addition errors, which equates to a mean of 1.67 addition errors per participant (SD 1.41), a mean of 0.84 addition errors per paragraph, and a mean of 0.15 omission errors per incorrectly written sentence.

\section{Total Collective Error Type}

All calculations are rounded to three decimal places. Within the 751 incorrectly written sentences, 2131 errors (excluding omission and addition errors) were identified. That is a mean of 31.338 errors per participant (SD 9.575), a mean of 15.669 errors per paragraph, and a mean of 2.837 errors for each incorrectly written sentence.

It should be noted that a single written error could fall into more than one error category and that there could be more than one error in each sentence. The following example illustrates this: One participant wrote "My bedroom have picture on the wall." The irregular verb have should be written as has. This would be considered a single verb error. However, the missing article $\boldsymbol{a}$, which should be written before the noun picture and is missing from the participants sentence, would be considered an omission error as well as an article error. Thus, omission and addition errors always involve the error to be categorised in two error groups. In addition, sentences can contain more than one error. The corrected sentence reads as, "My bedroom has a picture on the wall." which is a grammatically correct sentence with minimal correction. However, a better sentence would be, "There is a picture on the wall in my bedroom." 


\section{Ranked Error Types}

The distribution of the errors by error category is as follows:

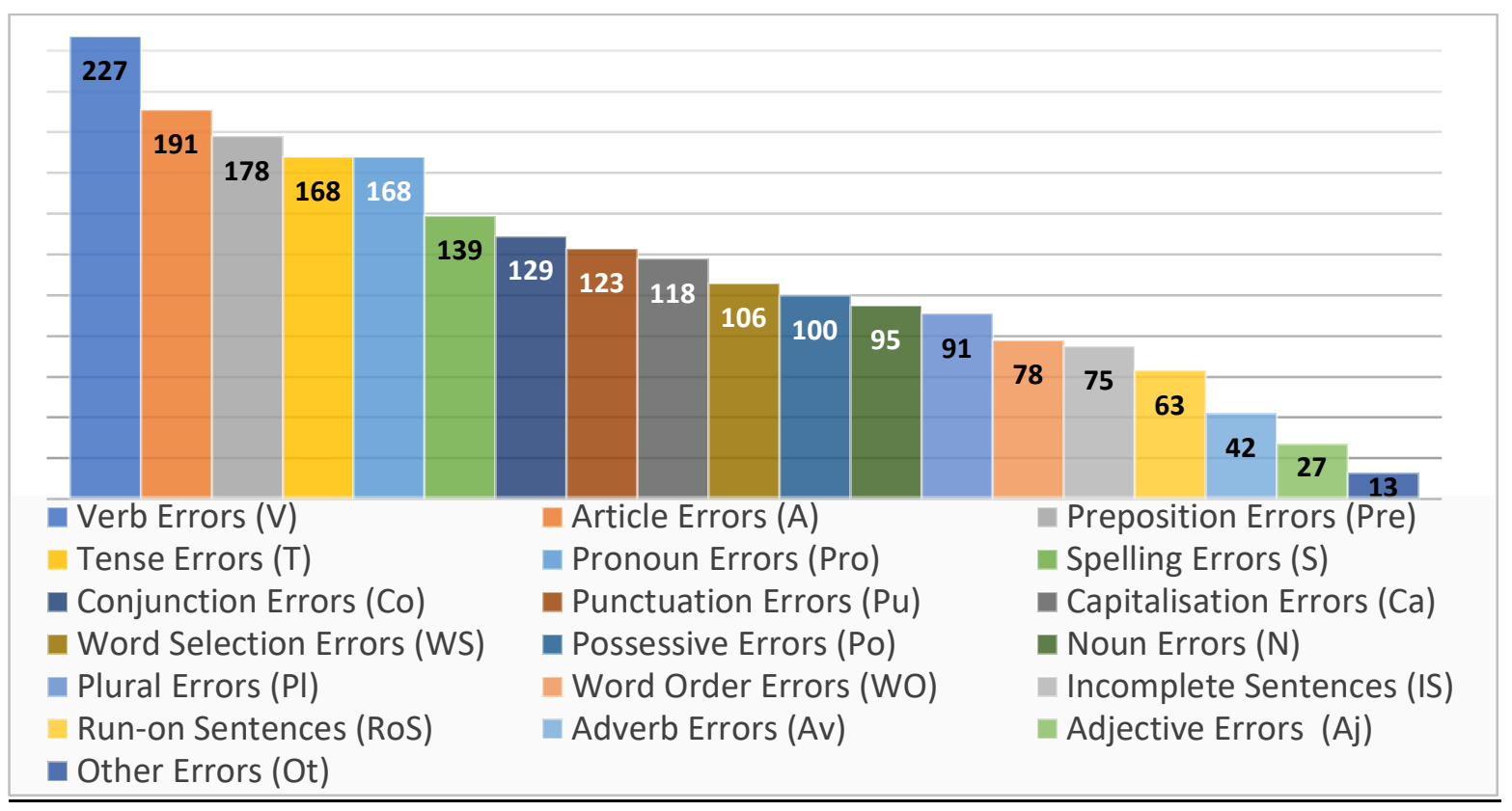

Figure 1: fs and Type of Errors Recorded in the 751 Incorrectly Written Sentences

Verb errors (V) were the most frequent errors identified in the 751 incorrectly written sentences. There were 227 verb errors identified. This is $10.652 \%$ of the total number of errors identified. There is a mean of 3.338 errors per participant with a standard deviation of 2.019, a mean of 1.669 errors per paragraph, and a mean of 0.302 errors for each incorrectly written sentence. An example of these types of errors was written by a participant, who wrote, "There are a lot of thing that good for me." Whilst there is a clear plural error (thing should written as things), the omission of the third person plural present form of 'to be' are, should be written between that and good. The corrected sentence reads as, "There are a lot of things that are good for me," which is now grammatically correct.

The second most frequent errors identified were article (A) errors. There were 191 article errors identified. This is $8.963 \%$ of the total number of errors identified. There is a mean of 2.809 article errors per participant with a standard deviation of 1.448, a mean of 1.404 article errors per paragraph, and a mean of 0.254 article errors for each incorrectly written sentence. An example of these types of errors was written by a participant, who wrote, "I have the bed blue colur." In this sentence, the definite article the should be written as an indefinite article $\boldsymbol{a}$. There are additional errors including a word order problem where the adjective blue should be written before the noun bed. The word colour is also unnecessary and incorrectly spelt. The corrected sentence reads as, "I have a blue bed."

The third most frequent errors identified were preposition (Pre) errors. There were 178 preposition errors identified. This is $8.353 \%$ of the total number of errors identified. There is a mean of 2.618 preposition errors per participant with a standard deviation of 2.22 , a mean of 1.309 preposition errors per paragraph, and a mean of 0.237 preposition errors for each incorrectly written sentence. An example of these types of errors was written by a participant, who wrote, "I only people on my school go to lern here." In this sentence, the preposition on is incorrect. The student should have written from as the correct preposition. The corrected sentence is written as, "I am the only person from my school to study here." As can be clearly seen, there were many other errors that needed correction in the participants original sentence.

The equal fourth most frequently identified errors were tense (T) errors and pronoun (Pro) errors. Both if these error types were identified 168 times, which is $7.884 \%$ of the total number of errors identified. There is a mean of 2.471 tense errors per participant with a standard deviation of 1.732, a mean of 1.235 tense errors per paragraph, and a mean of 0.224 tense errors for each incorrectly written sentence. An example of a tense error, as written by a participant is, "I will feeling good when I attended first show." In this sentence, the future tense will feeling, which is incorrectly written, should be written as the simple past participle felt. Hence, the corrected sentence reads as, "I 
An Analysis of Grammatical Errors Made By 3rd-Year Thai Business English Undergraduates When Spontaneously Writing Narrative and Descriptive Paragraphs

felt good when I attended the first show." Also note the omission of the definite article the, which has also been added to the corrected sentence.

The equal fourth-ranked error group was pronoun (Pro) errors, also numbered at 168, which is $7.884 \%$ of the total identified errors. There is a mean of 2.471 pronoun errors per participant with a standard deviation of 1.840 , a mean of 1.235 pronoun errors per paragraph, and a mean of 0.224 pronoun errors for each incorrectly written sentence. An example of a pronoun error, as written by a participant is, "When me feel sad sleepy." As well as being an incomplete sentence, the pronoun $\boldsymbol{m} \boldsymbol{e}$ is incorrect and should be written as $\boldsymbol{I}$. The corrected sentence is therefore written as, "My bed is the first place I go when I feel sad and sleepy." It is important to note that the teacher's additional words were due to joining two incomplete sentences to make one cogent sentence.

The sixth-ranked error group was spelling (S) errors. There were 139 spelling errors, which is $6.523 \%$ of the total number of errors identified. There is a mean of 2.044 spelling errors per participant with a standard deviation of 1.440 , a mean of 1.022 spelling errors per paragraph, and a mean of 0.185 spelling errors for each incorrectly written sentence. An example of these types of errors was written by a participant, who wrote, "The frist day at univercity is Lerning Critical Reading And Witing." There are multiple spelling errors in this sentence. The corrected sentence reads as, "On the first day at the university, I learned Critical Reading and Writing." Additional errors were also corrected, as seen.

The seventh most frequent errors identified were conjunction (Co) errors. There were 129 conjunction errors identified. This is $6.053 \%$ of the total number of errors identified. There is a mean of 1.897 conjunction errors per participant with a standard deviation of 1.317, a mean of 0.949 conjunction errors per paragraph, and a mean of 0.172 conjunction errors for each incorrectly written sentence. An example of these types of errors was written by a participant, who wrote, "I have a bedroom, my bedroom is small." In this sentence, the conjunction and is missing before my bedroom. This missing conjunction is also considered an omission error. Hence, the corrected sentence is written as "I have a bedroom, and it is small." This correction shows how the teacher's corrections took the simplest form. A better correction would be "I have a small bedroom.", which would make the attempted original compound sentence a simple sentence, and completely altering the original sentence type and structure.

The eighth most frequent errors identified were punctuation $(\mathrm{Pu})$ errors. There were 123 punctuation errors identified. This is $5.772 \%$ of the total number of errors identified. There is a mean of 1.809 punctuation errors per participant with a standard deviation of 1.374, a mean of 0.904 punctuation errors per paragraph, and a mean of 0.164 punctuation errors for each incorrectly written sentence. An example of a punctuation error, as written by a participant is, "My bedroom make me happy and its very messy to me" In this sentence, there is a missing apostrophe, a missing comma and a missing full stop. The corrected sentence reads as, "My bedroom makes me happy, and it's very messy to me." This is considered three punctuation errors.

The ninth most frequent errors identified were capitalisation ( $\mathrm{Ca}$ ) errors. There were 118 punctuation errors identified. This is $5.537 \%$ of the total number of errors identified. There is a mean of 1.761 capitalisation errors per participant with a standard deviation of 1.916, a mean of 0.868 capitalisation errors per paragraph, and a mean of 0.157 capitalisation errors for each incorrectly written sentence. An example of capitalisation errors, as written by a participant is, "i very happy with Subject because my Teacher Understand" In this sentence, there are four capitalisation errors. The corrected sentence reads as, "I am very happy with the subject because my teacher understands." This was recorded as four capitalisation errors.

The tenth-ranked error group was word selection (WS) errors. There were 106 word selection errors, which is $4.974 \%$ of the total number of errors identified. There is a mean of 1.559 word selection errors per participant with a standard deviation of 1.319 , a mean of 0.779 word selection errors per paragraph, and a mean of 0.141 word selection errors for each incorrectly written sentence. An example of these types of errors was written by a participant, who wrote, "Their are a lot of think that good in my bedroom." There are two word selection errors in this sentence. The corrected sentence reads as, "here are a lot of things in my bedroom that are good for me." Additional errors were also corrected, as seen.

The eleventh most frequent errors identified were possessive (Po) errors. There were 100 possessive errors identified. This is $4.693 \%$ of the total number of errors identified. There is a mean of 1.471 possessive errors per participant with a standard deviation of 1.511 , a mean of 0.735 possessive errors per paragraph, and a mean of 0.133 possessive errors for each incorrectly written sentence. An example of possessive errors, as written by a participant is, "I have a table, it's leg is breaked" In this sentence, there an unwarranted addition of an apostrophe altering the possessive pronoun. The corrected sentence reads as, "I have a table, and its leg is broken." Additional errors were 
Mr Anthony Goldsmith, and Ms Pattanan Sujaritjan

also corrected, as seen. A better correction would be, "I have a table with a broken leg," but using this correction would increase the number of errors, whereas the initial correction is grammatically correct and maintains the participant's original sentence structure.

The twelfth most frequent errors identified were noun $(\mathrm{N})$ errors. There were 95 noun errors identified. This is $4.458 \%$ of the total number of errors identified. There is a mean of 1.397 noun errors per participant with a standard deviation of 1.217, a mean of 0.698 noun errors per paragraph, and a mean of 0.126 noun errors for each incorrectly written sentence. An example of noun errors, as written by a participant is, "on the wall full of korean stars" In this sentence, there are multiple errors, including capitalisation errors, a verb error, a punctuation error and an adjective/addition error, as well as the missing noun. It is clear that the participant student cannot have 'actual' Korean stars on the bedroom wall. What the participant does have are pictures of Korean stars on her bedroom wall. Thus, there is a missing noun pictures. The corrected sentence reads as, "On the wall are pictures of Korean stars." Additional errors were also corrected, as seen.

The thirteenth most frequent errors identified were plural (Pl) errors. There were 91 plural errors identified. This is $4.270 \%$ of the total number of errors identified. There is a mean of 1.338 plural errors per participant with a standard deviation of 1.645 , a mean of 0.669 plural errors per paragraph, and a mean of 0.121 plural errors for each of the 751 incorrectly written sentences. An example of plural errors, as written by a participant is, "In my bedroom are two tabel where I play telephone game." The corrected sentence reads as, "In my bedroom are two tables where I play games on my telephone." Additional errors, including a missing preposition, a spelling error, a possessive pronoun error, as well as the two plural errors were also corrected, as seen.

The fourteenth most frequent errors identified were word order (WO) errors. There were 78 word order errors identified. This is $3.66 \%$ of the total number of errors identified. There is a mean of 1.147 word order errors per participant with a standard deviation of 1.055 , a mean of 0.574 word order errors per paragraph, and a mean of 0.104 word order errors for each of the 751 incorrectly written sentences. An example of word order errors, as written by a participant is, "I have a bed big and a bear brown color." The corrected sentence reads as, "I have a big bed and a brown bear." An addition error of the word colour is also corrected, as seen.

The fifteenth-ranked error group was incomplete sentence (IS) errors. There were 75 incomplete sentence errors identified, which is $3.519 \%$ of the total number of errors identified. There is a mean of 1.103 incomplete sentence errors per participant with a standard deviation of 1.317 , a mean of 0.551 incomplete sentence errors per paragraph, and a mean of 0.099 incomplete sentence errors for each incorrectly written sentence. An example of these types of errors was written by a participant, who wrote, "When I was at high school." This is a relative clause. The rest of the sentence was written as a separate sentence that read, "I went to many university to meet teacher." The corrected sentence reads as, "When I was at high school, I went to many universities to meet the teachers." The other errors were also corrected, as seen.

The sixteenth most frequent errors identified were run-on sentence (RoS) errors. There were 63 run-on sentence errors identified. This is $2.956 \%$ of the total number of errors identified. There is a mean of 0.926 run-on sentence errors per participant with a standard deviation of 1.083, a mean of 0.463 run-on sentence errors per paragraph, and a mean of 0.084 run-on sentence errors for each of the 751 incorrectly written sentences. An example of run-on sentence errors, as written by a participant is, "My bedroom make me happy, it is blue colour." The corrected sentence reads as, "Mv bedroom makes me happv. It is blue." A simpler correction could be,"My blue bedroom makes me happy." However making this correction would introduce a greater number of errors and also changes a compound sentence into a simple sentence, Whereas, the original correction is grammatically correct.

The seventeenth-ranked error group was adverb (Av) errors. There were 42 adverb errors identified, which is $1.971 \%$ of the total number of errors identified. There is a mean of 0.618 adverb errors per participant with a standard deviation of 0.754 , a mean of 0.309 adverb errors per paragraph, and a mean of 0.056 adverb errors for each incorrectly written sentence. An example of these types of errors was written by a participant, who wrote, "I go to the university quick in the morning." The corrected sentence reads as, "I go to the university quicklv in the morning." There were no additional errors in this sentence.

The eighteenth most frequent errors identified were adjective sentence (Aj) errors. There were 27 adjective errors identified, which is $1.267 \%$ of the total number of errors identified. There is a mean of 0.397 adjective errors per participant with a standard deviation of 0.650 , a mean of 0.199 adjective errors per paragraph, and a mean of 0.036 adjective errors for each incorrectly written sentence. An example of these types of errors was written by a participant, who wrote, "I like it because its a warm hot bedroom." This double adjective use is incorrect. The 
corrected sentence reads as, "I like it because it is a warm bedroom." An alternative correction could be "I like it because it is a hot bedroom." The additional error was also corrected, as seen.

The nineteenth and least frequent error group identified was the other (Ot) errors group. There were 13 other errors identified, which is $0.61 \%$ of the total number of errors identified. There is a mean of 0.191 adjective errors per participant with a standard deviation of 0.396 , a mean of 0.096 adjective errors per paragraph, and a mean of 0.017 adjective errors for each incorrectly written sentence. An example of these types of errors was written by a participant, who wrote, "the biggin is no a treas" This sentence makes no discernible sense and it was not possible to decipher a meaning. Without being able to interpret the sentence, it was not possible to identify the errors. It was therefore classified as an 'other' error, along with 12 other similar indecipherable sentences.

\section{Gender Results And Sentences}

Following the initial data analysis, the numerical data was divided by gender. There were fifty-four female participants and fourteen male participants. All of the mean scores and standard deviation scores were calculated and a two-sample t-test was performed on all of the paired data to determine whether the samples from two independent gender populations provide evidence that, the populations had significantly different means. These series of tests were calculated using the British Statistical Service's Two-Sample t-test calculator to determine the pvalues for each data pair.

The general sentence data by gender is reviewed first, and this is followed by a brief review of paired data that has a level of significance ( $p$-value) of $<0.1$. Any p-values that were $<0.05$ were considered highly significant.

The total number of paragraphs written was 136 and shows the every student wrote two paragraphs each or one for each exercise. The participant wrote 837 sentences, of which 685 were written by females and 152 were written by the male participants. This large difference is expected given the different gender sample sizes. More understandable and meaningful are the mean scores, the standard deviation scores, and the p-value, which are:

Table 3: The Total Number, Mean and Standard Deviation of Sentences Written by Each Gender Sample

\begin{tabular}{|c|c|}
\hline Totals Female & 685 \\
\hline Female Mean & 12.685 \\
\hline Female SD & 6.090 \\
\hline M/F t-Test p-value $=$ & $\underline{0.271}$ \\
\hline Totals Male & 152 \\
\hline Male Mean & 10.857 \\
\hline Male SD & 5.216 \\
\hline
\end{tabular}

This table shows an insignificant $\mathrm{p}$-value of 0.271 . However, it is interesting to note that the female participants wrote an average of $16.84 \%$ more sentences than their male counterparts. The sentences were categorised into three sentence types and the distribution of the sentence types is shown in the following graph.

The mean standard deviation scores, and p-values for the above sentence categories by gender are as follows:

Table 4: Sentence Number and Type with Mean Standard Deviation and p-values

\begin{tabular}{|c|c|c|c|c|}
\hline & All Sentences & Simple Sentences & Compound Sentences & Complex Sentences \\
\hline Totals Female $\mathrm{f}_{\mathrm{s}}$ & 685 & 481 & 96 & 108 \\
\hline Female Mean & 12.685 & 8.907 & 1.778 & 2.000 \\
\hline Female SD & 6.090 & 5.055 & 1.313 & 1.660 \\
\hline M/F t-Test p-value & 0.271 & 0.387 & $\mathbf{0 . 0 5 2}$ & 0.457 \\
\hline Totals Male $\mathrm{f}_{\mathrm{s}}$ & 152 & 108 & 13 & 32 \\
\hline Male Mean & 10.857 & 7.714 & 0.929 & 2.286 \\
\hline Male SD & 5.216 & 4.358 & 1.385 & 1.139 \\
\hline
\end{tabular}

As shown in table 4, the p-value for the compound sentences by gender is 0.052 , which is considered highly significant. The difference in the mean scores shows that the female participants wrote an average of $91.388 \%$ more compound sentences than that of their male counterparts. 
There were no significant differences between the gender samples regarding their number of correct and incorrect sentences.

Table 5: Correctly and Incorrectly Written Sentences with Mean, Standard Deviation, and T-Test P-Values by Gender

\begin{tabular}{|c|c|c|}
\hline & Correctly Written Sentences & Incorrectly Written Sentences \\
\hline Female Sentences & 75 & 610 \\
\hline Female Mean & 1.389 & 11.296 \\
\hline Female SD & 1.785 & 5.517 \\
\hline M/F t-test p-value & 0.303 & 0.411 \\
\hline Male Sentences & 11 & 141 \\
\hline Male Mean & 0.786 & 10.071 \\
\hline Male SD & 1.929 & 4.698 \\
\hline
\end{tabular}

\section{Gender Omission and Addition Errors}

When looking at the omission and addition errors, there was no significant difference between the gender samples. The numerical data for the gender samples and their omission and addition error data are in table 5.

Table 5: Omission and Addition Sentences with Mean, Standard Deviation, and t-test p-Values by Gender

\begin{tabular}{|c|c|c|c|}
\hline & Addition Errors & Omission Errors & Addition and Omission Errors \\
\hline Female Sentences $\mathrm{f}_{\mathrm{s}}$ & 86 & 500 & 586 \\
\hline Female Mean & 1.593 & 9.259 & 10.852 \\
\hline Female SD & 1.325 & 5.780 & 6.335 \\
\hline M/F t-test p-value & 0.419 & 0.469 & 0.364 \\
\hline Male Sentences $\mathrm{f}_{\mathrm{s}}$ & 28 & 146 & 174 \\
\hline Male Mean & 2.000 & 10.492 & 12.429 \\
\hline Male SD & 1.929 & 4.698 & 5.501 \\
\hline
\end{tabular}

\section{Gender Error Types}

When looking at the remaining error types by gender, only those that show a high level of significance (t-test pvalue of $<0.1$ ) are reviewed. These error types will be reviewed and described in ranked order, starting with the highest ranked group.

Three error types will be reviewed.

The highest ranked error type with a significant p-value is the seventh ranked error type: Conjunction (Co) Errors ( $\left.f_{s} 129\right)$. The total, female, and male data is shown in table 6 below.

Table 6: Conjunction Sentence Errors with Mean, Standard Deviation, and T-Test P-Values by Gender Samples

\begin{tabular}{|c|c|c|c|}
\hline \multicolumn{4}{|c|}{ Conjunction Errors (Co) } \\
\hline Female $\mathrm{f}_{\mathrm{s}}$ sentences & 110 & Male $_{\mathrm{s}}$ sentences & 19 \\
\hline Female mean & 2.037 & Male Mean & 1.357 \\
\hline Female SD & 1.317 & Male SD & 1.216 \\
\hline \multicolumn{2}{|c|}{ M/F t-test p-value = 0.081 } \\
\hline
\end{tabular}

Table 6 clearly shows a highly significant mean score difference with a t-test p-value of 0.081 . It is clear that the female group wrote $50.11 \%$ more conjunction errors per female participant than their male counterparts.

The second error group with a significant t-test $\mathrm{p}$-value result is the eighth ranked, punctuation $(\mathrm{Pu})$ error group $\left(f_{s} 123\right)$. The results are shown in table 7.

Table 7: Punctuation Sentence Errors with Mean, Standard Deviation, and T-Test P-Values by Gender Samples

\begin{tabular}{|l|c|l|c|}
\hline \multicolumn{4}{|c|}{ Punctuation Errors (Pu) } \\
\hline Female $\mathrm{f}_{\mathrm{s}}$ sentences & 106 & Male $\mathrm{f}_{\mathrm{s}}$ sentences & 17 \\
\hline
\end{tabular}


An Analysis of Grammatical Errors Made By 3rd-Year Thai Business English Undergraduates When Spontaneously Writing Narrative and Descriptive Paragraphs

\begin{tabular}{|c|c|c|c|}
\hline Female mean & 1.963 & Male Mean & 1.214 \\
\hline Female SD & 1.414 & Male SD & 1.051 \\
\hline \multicolumn{4}{|c}{ M/F t-test p-value 0.037 } \\
\hline
\end{tabular}

Table 7 above shows a highly significant mean score difference with a t-test $p$-value of 0.037 . It is clear that the female group wrote $61.7 \%$ more punctuation errors per female participant than their male counterparts.

The third and final error group with a significant $t$-test $p$-value result is the twelfth ranked, noun (N) error group $\left(f_{s} 95\right)$. The results are shown in table 8.

Table 8: Noun Sentence Errors with Mean, Standard Deviation, and T-Test P-Values by Gender Samples

\begin{tabular}{|c|c|c|c|}
\hline \multicolumn{4}{|c|}{ Noun Errors $(\mathrm{N})$} \\
\hline Female $\mathrm{f}_{\mathrm{s}}$ sentences & 85 & Male $\mathrm{f}_{\mathrm{s}}$ sentences & 10 \\
\hline Female mean & 1.574 & Male Mean & 0.714 \\
\hline Female SD & 1.283 & Male SD & 0.994 \\
\hline \multicolumn{4}{|c|}{ M/F t-test p-value 0.012} \\
\hline
\end{tabular}

Table 8 above shows a highly significant mean score difference with a t-test $p$-value of 0.012 . It is clear that the female group wrote $120.45 \%$ more noun errors per female participant than their male counterparts.

It is important to note that the three significant results all show that the female participants made a significantly higher number of errors in the three error groups identified. However, it is important to highlight that it was the female participants that, on average, wrote nearly twice as many correctly written sentences per female participant (mean $=1.389)$ than their male counterparts $($ mean $=0.786)$. The female participants, on average, also attempted to write nearly twice as many compound sentences than their male counterparts.

\section{DISCUSSION}

The above research findings will now be briefly reviewed, compared, and contrasted with the findings of contemporary research conducted in Thailand by other researchers in this field.

Phuket and Othman [52] (2015) reviewed 40 essays written by 40 native Thai English major undergraduates. They found twenty-two emergent error types, which included wrong verb tense; wrong verb form; pronouns (omission, addition or wrong choice); pronouns; inappropriate use; prepositions (omission, addition or wrong choice); articles; nouns; adjective (position); adjective (comparison); conjunctions; infinitive and gerund; subjectverb agreement; sentence fragment; translated word from Thai; word choice; confusion of sense relations; collocation; question mark; comma; full stop; capitalization; and spelling. The errors found in their research follow a similar error profile to the ones identified in this research.

Iamsui [53] (2014) studied 20 undergraduate student essays. She only used five error categories, which included sentence structure, connecting words, subject-a verb agreement, word choice and word order. Word choice was found to be the most frequent error made (41.1\%), followed by sentence structure errors $(36.17 \%$, subject-verb agreement $(13.48 \%)$, word order $(10.64 \%)$, and connecting word errors $(0.35 \%)$. Whilst this research did identify some errors, the limitation of only having five error types bore minimal results that cannot be directly compared to this study.

Kuptanaroaj [54] (2014) reviewed the written errors of 80 3rd-year Thai English major undergraduates. She used an error analysis framework created by Ellis and Barkhuizen [55] (2005) as a guide for her analysis. She found over 1000 errors, which is much closer to the error numbers identified in this research. She used eleven error types, which were sentence fragment (20.57\%), subject-verb agreement (15.85\%), noun ending $(13.58 \%)$, verb form (12.17\%), word form (11.89), preposition (8.87\%), determiner (6.60\%), verb tense (3.58\%), punctuation (2.64\%), run-ons (2.26\%), and word order (1.51\%). Whilst Kuptanaroaj (2014) used fewer error types in her research, she did show a proportion of errors that were similar to those found in this research project.

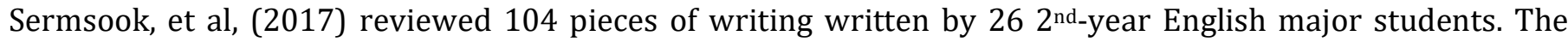
researchers identified seventeen error types in the students' written works. However, they only found 296 errors in the 104 pieces of written work. The length of the written works and the students' preparation was also not indicated. Also, whether they found more than one error within one sentence is not clear in the article. They found errors in: 
Mr Anthony Goldsmith, and Ms Pattanan Sujaritjan

1st Punctuation (42,14.19\%), 2nd Articles (39, 13.18\%), 3rd Subject verb (35, 11.82\%), 4th Spelling (29, 9.8\%), 5th Capitalisation (24, 8.12\%), 6th Fragment (23, 7.77\%), 7th Verbs (17, 5.74\%), 8th Prepositions (15, 5.07\%), 9th Literal translation from Thai $(14,4.73 \%)$, 10th Nouns $(12,4.05 \%)$ and Pronouns $(12,4.05 \%), 12$ th Word choices (11 3.72\%), 13th Tense (10, 3.38\%), 14th Word order (5, 1.69\%), 15th Adjectives (3,1.01\%) and Parts of speech (3, $1.01 \%)$, and 17 th Transition words $(2,0.67)$.

Promsupa et al. [56] reviewed 34 English essays written by 34 Thai English major undergraduates. They identified 2,218 errors in 2 main types and 32 sub-types. The two main types were considered Morphological errors (deviant forms of English writing in a word level) and Syntactic errors (deviant forms of English writing in a sentence level). Morphological errors includes 1) Noun form errors, 2) Singular/plural errors, 3) Pronoun errors, 4) Present errors, 5) Past errors, 6) Subject-verb agreement errors, 7) Gerund errors, 8) Infinitive errors, 9) Model/auxiliary errors, 10) Adjective errors, 11) Adverb errors, 12) Possessive errors, 13) Preposition errors, 14) Article errors, 15) Possessive (determiner) errors, and 16) Demonstrative errors. Syntactic errors includes 1) Word order errors, 2) Run-on/ comma splice errors, 3) Fragment errors, 4) Omission of subjects, 5) Omission of verbs/actions, 6) Omission of objects/compliments, 7) 'There' structure errors, 8) AND-type errors, 9) BUT-type errors, 10) OR-type errors, 11) So-type errors, 12) Noun clause/phrase errors, 13) Adjective clause/phrase errors, 14) Adverbial clause/phrase errors, 15) Passive voice errors, and 16) Comparison errors. This research showed singular/plural errors as the most frequent errors made. Past tense errors were the least frequent errors identified.

These research examples and others by Tiensawangchai, T. (2014), Watcharapunyaw-ong, S. \& Usaha, S. (2013), Sukasame, Kantho, \& Narrot, (2013), and Phettongkam [57], H. (2013), all indicate a wide variety of error types and error frequency. Whilst many of the error types were included in more than one of the pieces of research, the number of error types varied between 5 in one piece of research and 32 in another. This large disparity of error types and the variable number of errors identified make direct comparison of results difficult. The differences in error frequency may be related to the geographical region of Thailand. The EF English Proficiency Index (2019) clearly shows a difference of English proficiency levels between the four regions of Thailand with the Northeast having the lowest proficiency level (43.32) in Thailand and the Central region having the highest proficiency score in Thailand (50.1). However, Thailand as a whole remains in the very low English proficiency category and Thailand's northeastern score would put this region in 95th lowest proficiency level out of the 100 countries reviewed in the EF EPI longitudinal study. What is clear is that Thai students continue to make many errors when attempting to write English.

At the time of writing, no other studies reviewed gender impact upon writing structures and errors. Thus, reviewing the data in this research in relation to other researchers is not possible.

\section{CONCLUSIONS AND RECOMMENDATIONS}

This research has reviewed 138 paragraphs written by 68 3rd-year Business English undergraduates at UBRU.

There has been a plethora of research projects that have reviewed writing errors made by Thai EFL students. They have all shown that error writing is a common issue for EFL learners in Thailand. It is recognised that these research projects have all used differing methods of error identification and categorisation, which makes comparisons difficult.

This research project has added to and reinforced the observations of the researchers who have previously shown that writing English remains problematic for the EFL students at UBRU, and in Thailand.

The results of this research project have implications for pedagogical attention and change towards a model of English language education that has a proven record of providing real pragmatic benefit for the Thai students who are studying Business English at UBRU.

\section{Recommendations}

1) A review of the educational model used within the BE department.

2) Incorporation of an educational writing model that is part of a proven educational system, which must be student focused and have pragmatic benefits that are cost-effective.

3) Further review of all BE students writing ability on an annual basis to assess student progression.

4) Curricula change that reflect international EFL education that has a proven pragmatic record of accomplishment. 
5) A decisive move away from the grammar-translation model, which has been shown to create educational disadvantages for students, whilst being 'easy' for teachers.

6) Assessment of the Thai English teachers writing and error recognition ability should be done as it has been previously demonstrated that many of the difficulties experienced by the EFL learners are also difficult for the Thai EFL teachers. This would help determine a basis for remedial English writing skills development that could be an ongoing part of their professional development.

\section{APPENDICES}

\section{APPENDIX A}

An error taxonomy based upon those used by Na-grams (2005) and Watcharapunyawong's (2013) and then adapted to identify and equate the following 23 grammar errors types made by the students., as used in this research.

- Punctuation Errors

- Capitalisation Errors

- $\quad$ Spelling Errors

- Run-on Sentences

- Incomplete Sentences

- Addition Errors

- Word Selection Errors

- Word Order Errors

- Tense Errors

- Clause Errors

- Plural Errors

- Article Errors

- Preposition Errors

- Pronoun Errors

- Subject-verb Agreement Errors

- Possessive Errors

- Verb Errors

- Conjunction Errors

- Adverb Errors

- Adjective Errors

- Noun Errors

- Omission Errors

- Other Errors

\section{APPENDIX B}

Table 9: A Summary of the Distribution of Error Types by Ranked Order, Frequency, Percentage, Participant Mean and Standard Deviation, and Paragraph/Sentence Mean

\begin{tabular}{|c|c|c|c|c|c|}
\hline Error Type & Error Frequency & Error Percentage & Participant Mean/(SD) & Paragraph Mean & Sentence Mean \\
\hline Verb & 227 & $10.652 \%$ & $3.338(2.019)$ & 1.669 & 0.302 \\
\hline Article & 191 & $8.963 \%$ & $2.809(1.448)$ & 1.404 & 0.254 \\
\hline Preposition & 178 & $8.353 \%$ & $2.618(2.220)$ & 1.309 & 0.237 \\
\hline Tense & 168 & $7.884 \%$ & $2.471(1.732)$ & 1.235 & 0.224 \\
\hline Pronoun & 168 & $7.884 \%$ & $2.471(1.840)$ & 1.235 & 0.224 \\
\hline Spelling & 139 & $6.523 \%$ & $2.044(1.440)$ & 1.022 & 0.185 \\
\hline Conjunction & 129 & $6.053 \%$ & $1.897(1.317)$ & 0.949 & 0.172 \\
\hline Punctuation & 123 & $5.772 \%$ & $1.809(1.374)$ & 0.904 & 0.164 \\
\hline Capitalisation & 118 & $5.537 \%$ & $1.761(1.916)$ & 0.868 & 0.157 \\
\hline
\end{tabular}


Mr Anthony Goldsmith, and Ms Pattanan Sujaritjan

\begin{tabular}{|c|c|c|c|c|c|}
\hline Word Choice & 106 & $4.974 \%$ & $1.559(1.319)$ & 0.779 & 0.141 \\
\hline Possessive & 100 & $4.693 \%$ & $1.471(1.511)$ & 0.735 & 0.133 \\
\hline Noun & 95 & $4.458 \%$ & $1.397(1.217)$ & 0.698 & 0.126 \\
\hline Plural & 91 & $4.270 \%$ & $1.338(1.645)$ & 0.669 & 0.121 \\
\hline Word Order & 78 & $3.660 \%$ & $1.147(1.055)$ & 0.574 & 0.104 \\
\hline Incomplete & 75 & $3.519 \%$ & $1.103(1.317)$ & 0.551 & 0.099 \\
\hline Run-on & 63 & $2.956 \%$ & $0.926(1.083)$ & 0.463 & 0.084 \\
\hline Adverb & 42 & $1.971 \%$ & $0.618(0.754)$ & 0.309 & 0.056 \\
\hline Adjective & 27 & $1.267 \%$ & $0.397(0.650)$ & 0.199 & 0.036 \\
\hline Other & 13 & $0.61 \%$ & $0.191(0.396)$ & 0.096 & 0.017 \\
\hline
\end{tabular}

\section{APPENDIX C}

Significant $\mathrm{p}$-values between the gender groups were identified in the following sentence structure and error types and are summarised in Table 10:

Table 10: The Mean Scores, Standard Deviation, and Significant T-Test P-Values Between the Male and Female Participant Groups

\begin{tabular}{|c|c|c|c|c|c|}
\hline \multirow{2}{*}{ Structure / Error Type } & \multicolumn{2}{|c|}{ Female } & \multicolumn{2}{c|}{ Male } & $\begin{array}{c}\text { Significant t-Test } \\
\text { p-value }\end{array}$ \\
\cline { 2 - 5 } & Mean Score & Standard Deviation & Mean Score & Standard Deviation & 0.052 \\
\hline Compound Sentences & 1.778 & 1.313 & 0.929 & 1.385 & 0.081 \\
\hline Conjunction Error & 2.037 & 1.317 & 1.357 & 1.126 & 0.037 \\
\hline Punctuation Errors & 1.963 & 1.414 & 1.214 & 1.051 & 0.012 \\
\hline Noun Errors & 1.574 & 1.283 & 0.714 & 0.994 & \\
\hline
\end{tabular}

\section{APPENDIX D}

A summary of the Error groups ranked, with the frequency and examples of students sentences.

\begin{tabular}{|c|c|c|c|c|}
\hline Rank & $\begin{array}{l}\text { Error } \\
\text { Type }\end{array}$ & $\mathrm{f}_{\mathrm{s}}$ & Respondent Example Sentence & Teacher Corrected Sentence \\
\hline $1^{\text {st }}$ & $(\mathrm{V})$ & 227 & There are a lot of thing that good for me. & There are a lot of things that are good for me. \\
\hline $2^{\text {nd }}$ & $(\mathrm{A})$ & 191 & I have the bed blue colur. & I have $\underline{a}$ blue bed. \\
\hline $3^{\text {rd }}$ & (Pre) & 178 & I only people on my school go to lern here. & $\begin{array}{c}\text { I am the only person from my school to study } \\
\text { here. }\end{array}$ \\
\hline $4^{\text {th }}$ & $(\mathrm{T})$ & 168 & $\begin{array}{l}\text { I will feeling good when I attended first } \\
\text { show. }\end{array}$ & I felt good when I attended the first show. \\
\hline $4^{\text {th }}$ & (Pro) & 168 & When me feel sad sleepy. & $\begin{array}{c}\text { My bed is the first place I go when I feel sad } \\
\text { and sleepy. }\end{array}$ \\
\hline $6^{\text {th }}$ & $(\mathrm{S})$ & 139 & $\begin{array}{l}\text { The frist day at univercity is Lerning } \\
\text { Critical Reading And Witing. }\end{array}$ & $\begin{array}{l}\text { On the first day at the university, I learned } \\
\text { Critical Reading and Writing. }\end{array}$ \\
\hline $7^{\text {th }}$ & (Co) & 129 & I have a bedroom, my bedroom is small. & I have a bedroom, and it is small. \\
\hline $8^{\text {th }}$ & $(\mathrm{Pu})$ & 123 & Its make me happy and its very messy to me & It makes me happy ${ }_{k}$ and it's very messy to me. \\
\hline $9^{\text {th }}$ & (Ca) & 118 & $\begin{array}{c}\text { i very happy with Subject because my } \\
\text { Teacher Understand }\end{array}$ & $\begin{array}{l}\text { I am very happy with the subject because my } \\
\text { teacher } \underline{\underline{u}} \text { nderstands. }\end{array}$ \\
\hline $10^{\text {th }}$ & (WS) & 106 & $\begin{array}{l}\text { There are a lot of think that good in my } \\
\text { bedroom. }\end{array}$ & $\begin{array}{c}\text { There are a lot of things in my bedroom that } \\
\text { are good for me. }\end{array}$ \\
\hline $11^{\text {th }}$ & (Po) & 100 & I have a table, it's leg is breaked & I have a table, and its leg is broken. \\
\hline $12^{\text {th }}$ & $(\mathrm{N})$ & 95 & on the wall full of korean stars & On the wall are pictures of Korean stars. \\
\hline $13^{\text {th }}$ & (Pl) & 91 & $\begin{array}{c}\text { In my bedroom are two tabel where I play } \\
\text { telephone game. }\end{array}$ & $\begin{array}{l}\text { In my bedroom are two tables where I play } \\
\text { games on my telephone. }\end{array}$ \\
\hline
\end{tabular}


An Analysis of Grammatical Errors Made By 3rd-Year Thai Business English Undergraduates When Spontaneously Writing Narrative and Descriptive Paragraphs

\begin{tabular}{|c|c|c|c|c|}
\hline $14^{\text {th }}$ & (WO) & 78 & I have a bed big and a bear brown color. & I have a big bed and a brown bear. \\
\hline $15^{\text {th }}$ & (IS) & 75 & $\begin{array}{c}\text { When I was at high school. I went to many } \\
\text { university to meet teacher. }\end{array}$ & $\begin{array}{l}\text { When I was at high school, I went to many } \\
\text { universities to meet the teachers. }\end{array}$ \\
\hline $16^{\text {th }}$ & $(\mathrm{RoS})$ & 63 & $\begin{array}{c}\text { My bedroom make me happy, it is blue } \\
\text { colour. }\end{array}$ & Mv bedroom makes me happv. It is blue. \\
\hline $17^{\text {th }}$ & $(\mathrm{Av})$ & 42 & I go to the university quick in the morning. & I go to the university quickly in the morning. \\
\hline $18^{\text {th }}$ & $(\mathrm{Aj})$ & 27 & I like it because its a warm hot bedroom. & $\begin{array}{c}\text { I like it because it is a warm bedroom. } \\
\text { Or: } \\
\text { I like it because it is a hot bedroom. }\end{array}$ \\
\hline $19^{\text {th }}$ & $(\mathrm{Ot})$ & 13 & the biggin is no a treas & ????????????? \\
\hline
\end{tabular}

\section{SOURCES OF FUNDING}

This research received no specific grant from any funding agency in the public, commercial, or not-for-profit sectors.

\section{CONFLICT OF INTEREST}

The author have declared that no competing interests exist.

\section{ACKNOWLEDGMENT}

This paper and the research behind it would not have been possible without the financial support of Faculty of Humanities and Social Sciences, UBRU. We are especially indebted to Assistant Professor Dr.Phusit Chatwiriyawong, Dean of faculty and Asst.Dr. Anan Thaptha, Deputy Dean of Research who have been supportive of our research goals.

Finally, we thank Dr. Chayada Budwong, English lecturer, for her comments that helped us refine the manuscript.

\section{REFERENCES}

[1] Foley, J.A. (2006) English as a lingua franca. International Journal of the Sociology of Language, 177, 51-65.

[2] Block, D. English and Globalisation. Routledge. 2002

[3] Crystal, D. English as a global language. 2003, Longman

[4] Holliday, J. Brown, K. Cultural factors affecting Chinese ESL students' academic learning. Education, 2009, 129(4), 643-653.

[5] Nunan, D. English as a global language. TESOL, 2001, Quarterly, 39, p.p.235-261.

[6] Lado, R. Linguistics Across Cultures. 1964, University of Michigan Press, Ann Arbor

[7] Jiang, M. C. An analysis of Chinese ESL learns' errors in prepositions. Journal of National Chiayi Institute of Agriculture, 1995, 41, 187-201.

[8] Yu, L. The role of L1 in the acquisition of motion verbs in English by Chinese and Japanese learners. Canadian Modern Language Review, 1996, 53, 191-218

[9] Mori, Y. Effects of First Language and Phonological Accessibility on Kanji Recognition. The Modern Language Journal, 1998, 82(1), 69-82.

[10] Jarvis, S. Methodological rigor in the study of transfer: Identifying L1 influence in the interlanguage lexicon. Language Learning. 2000, 50(2), 245-309.

[11] Collins, L. The role of L1 influence and lexical aspect in the acquisition of temporal morphology. Language Learning, 2002, 52(1), 43-94.

[12] Chen, C. Y., \& Huang, H. Y. L2 acquisition of subject-prominence by EFL students in Taiwan. English Teaching \& Learning, 2003, 27(4), 99-122. 
[13] Goldsmith, A. Dennis AN ILLUMINATION OF 3rd YEAR, THAI ENGLISH-MAJOR UNDERGRADUATE STUDENTS' PERCEPTIONS OF NATIVE AND THAI ENGLISH TEACHERS. Internal Journal of Research, 2016, Vol 4 (Iss.7): July, 2016, Granthaalayah.

[14] Wachs, S. Breaking the writing barrier: Approaches to the composition class. A Handbook for Teaching English at Japanese Colleges and Universities. 1993, Oxford: Oxford University Press

[15] Kantabutra, B. Teachers apply here $\quad$ Bangkok $\quad$ Post, 2015 https://www.bangkokpost.com/opinion/opinion/766592/teachers-apply-here

[16] Richards, J. C. \& Renandya, W. A. Methodology in Language Teaching: An Anthology of Current Practice. 2002, Cambridge: Cambridge University Press.

[17] Noon-ura, S. English Teaching Problems in Thailand and Thai Teachers' Professional Development Needs. English Language Teaching: 2013, Vol. 6, No. 11.

[18] Wiriyachitra, A. English Language Teaching and Learning in Thailand in this Decade. 2013 https://www.academia.edu/11373994/English_Language_Teaching_and_Learning_in_Thailand_in_this_Dec ade.

[19] Dixon, L. Zhao, J. Wu, S. Su, J. Burgess, R. Gezer, M. Snow, C. What we know about second language acquisition: a synthesis from four perspectives. Review of Educational Research, 2012, 82(1), 5-60.

[20] Fitriyanti. R. Soraya, A. Grammar Translation Method. 2011, https://novaekasari09.wordpress.com/2011/06/12/grammar-translation-method/.

[21] EF EPI, EF English Index. https://www.ef.com/wwen/epi/ 2019

[22] Brown, H.D. Principles of Language Learning and Teaching. 1994, Englewood Cliffs, N.J: Prentice-Hall

[23] Gass, S. and Selinker, L. Second Language Acquisition: An Introductory Course. 1994, Hilsdale, NJ: Lawrence Erlbaum.

[24] Norrish, J. Language learners and their errors. London: 1983, The Macmillan Press

[25] Corder, S.P. The significance of learners' errors. International Review of Applied Linguistics, 1967, 5 (4)

[26] White, R. and Arndt, V. Process Writing Harlow: 1991, London

[27] Carroll, S. and Swain, M. Explicit and implicit negative feedback: An empirical study of linguistic generalizations. Studies in Second Language Acquisition. 1993, 15/3

[28] Burt, K.M. \& C. Kiparsky. The Gooficon, 1994, Mass. Newbury House Publishers

[29] Kuntjara, E. Limengka, P, E. TYPES OF GRAMMATICAL ERRORS IN THE ESSAYS WRITTEN BY FOURTHSEMESTER STUDENTS OF ENGLISH DEPARTMENT, PETRA CHRISTIAN UNIVERSITY. Semantic Scholar, 2013, https://www.semanticscholar.org/paper/TYPES-OF-GRAMMATICAL-ERRORS-IN-THE-ESSAYS-WRITTENLimengka-untjara/40e0cf8b5910db7af09339933f66b5b45a55a74e

[30] Dulay, H. C., Burt, M.K., \& Krashen, S.D. Language two. 1982, New York: Oxford University Press

[31] Lim Ho Peng. Errors and error analysis in TESL: The Malaysian experience. RELC Journal. 1976, 9(2)

[32] Sridhar, S. N. Contrastive analysis, error analysis, and interlanguage. IN: J. Fisiak (ed.) Contrastive linguistics and the language teacher. 1980, Oxford: Pergamon Press.

[33] Owe-Ewie, C. Williams, R Grammatical and Lexical Errors in Students' English Composition Writing: The Case of Three Senior High Schools (SHS) in the Central Region of Ghana. Sino-US English Teaching, 2017, August, Vol. 14, No. 8, 463-482

[34] Hamzah. AN ANALYSIS OF THE WRITTEN GRAMMATICAL ERRORS PRODUCED BY FRESHMENT STUDENTS IN ENGLISH WRITING Lingua Didaktika 2012, Volume 6 No 1, December

[35] Etherton, A, R, B. Error Analysis: Problems and Procedures. English Language Teaching Journal. 1977, v30 n1

[36] Singh, C. Singh, A. Razak, N. \& Ravinthar, T. Grammar Errors Made by ESL Tertiary Students in Writing. English Language Teaching; 2017, Vol. 10, No. 5

[37] Bennui, P. A Study of L1 Interference in the Writing of Thai EFL Students. Malaysian Journal Of ELT Research, 2008, Vol 4, pp. 72-102.

[38] อรษา ร้อยแก้ว An Analysis of Grammatical Errors In English Job Application Letters Written by Agricultural Technology Students at King Mongkut's Institute of Technology Ladkrabang, Bangkok, Thailand, 2008.

[39] Kaewnuch, S. Boonsue, W. Thai Students' Ability in Analyzing Syntactic Errors: A Case Study from an English Error Analysis Class, 2012, บทความวิจัย (มค-มิย 56 
An Analysis of Grammatical Errors Made By 3rd-Year Thai Business English Undergraduates When Spontaneously

Writing Narrative and Descriptive Paragraphs

[40] Sukasame, N. Kantho, Dr, S. Narrot, Dr, P A study of errors in learning English Grammatical structures on Tenses of MatthayomSuksa 4 Students of The Demonstration School, KhonKaen University. Procedia - Social and Behavioral Sciences 116,2013, $1934-1939$

[41] Watcharapunyaw-ong, S. \& Usaha, S. Thai EFL Students' Writing Errors in Different Text Types: The Interference of the First Language. English Language Teaching; 2013, Vol. 6, No. 1, Canadian Center of Science and Education

[42] Tiensawangchai, T. TYPES OF GRAMMAR ERRORS FOUND IN THAI EFL STUDENTS' BUSINESS WRITING. 2014, International Journal of Arts \& Sciences

[43] James, C. Errors In Language Learning And Use: Exploring Error Analysis. 1998, Addison Wesley Longman Limited.

[44] Nonkukhetkhong, K. Grammar error analysis of the first year English major students, Udon Thani Rajabhat University. Proceedings of the Asian conference on language learning 2013. (pp. 117-126).

[45] Lush, B. Writing errors: A case study of Thai students' writing errors. Thai TESOL BULLEIN, 2002, 15(1). 7582.

[46] Thep-Ackropong, T Teaching English in Thailand: An Uphill Battle. 2005, ejournals.swu.ac.th pp, 51-62

[47] Goldsmith, A. Teaching English in Thailand and the Plight of Thai Students' English Proficiency - A Personal Account. 2015 Unpublished article written as part of an MA English degree.

[48] Boonyarattanasoo-ntorn, P. An investigation of Thai students' English language writing difficulties and their use of writing strategies Journal of Advanced Research in Social Sciences and Humanities, 2017, Volume 2, Issue 2 (111-118)

[49] Khumphee, S. Yodkamlue, B Grammatical Errors in English Essays Written by Thai EFL Undergraduate Students. Journal of Education, Mahasarakham University. 2017, Vol 11 Number 4, Oct-Dec

[50] Sermsook, K. Liamnimitr, J. \& Pochakorn, R. An Analysis of Errors in Written English Sentences: A Case Study of Thai EFL Students. English Language Teaching; 2017, Vol. 10, No. 3; Canadian Center of Science and Education

[51] The Nation Thailand. In teaching English, say it first, grammar later. September 22, 2015. https://www.nationthailand.com/opinion/30269332

[52] Phuket, P. \& Dr Othman, N. Understanding EFL Students' Errors in Writing. Journal of Education and Practice 2015, Vol.6, No.32, 2015

[53] Iamsiu, C. An Analysis of Grammatical Errors in Srinakharinwirot University Students' Writing. A Master's Project, 2014, Presented in Partial Fulfilment of a Masters of Arts Degree in English at Srinakharinwirot University.

[54] Kuptanaroaj, N. An Analysis of Grammatical Errors in English Essays Written by the Undergraduate Students at Rangsit University. 2019, RSU International Research Conference

[55] Ellis, R. \& Barkhuizen, G. Analysing Learner Language. 2005, Oxford: Oxford University Press.

[56] Promsupa, P. Varasarin, P. Brudhiprabha, P. An Analysis of Grammatical Errors in English Writing of Thai University Students. HRD JOURNAL Volume 8. Number 1. June, 2017.

[57] Phettongkam, H. Error analysis and its' implications in communicative English Language teaching. Thammasat Review, 2013, Special Issue

[58] Abushihab, I. An Analysis of Grammatical Errors in Writing Made by Turkish Learners of English as a Foreign Language. International Journal of Linguistics, ISSN 1948-5425, 2014, Vol. 6, No. 4

[59] Al-Shujairi, J. and Tan, H. (). Grammar Errors in the Writing of Iraqi English Language Learners. 2017, Published by Australian International Academic Centre PTY.LTD

[60] Aziz, S. Kashif, M. and Aijaz. M. English Grammar Problems Seen in the Original Articles Submitted for Publication in Annals of Abbasi Shaheed Hospital and Karachi Medical and Dental College Journal of the College of Physicians and Surgeons Pakistan 2016, Vol. 26 (8): 681-684

[61] Blaxter L, Hughes C, \& Tight M. How to Research FOURTH EDITION. 2010 Open University Press

[62] Bosuwon, T. A Study of EFL Teachers' Awareness and Tolerance of Thai Undergraduate Students' Syntactic Writing Errors. 2013, University of the Thai Chamber of Commerce

[63] Editor. (2015) In teaching English, say it first, grammar. The Nation Thailand. https://www.nationthailand.com/opinion/30269332

[64] Editor. (2019) EF English Proficiency Index. https://www.ef.com/wwen/epi/regions/asia/thailand/ 
[65] Galasso, J. (2002) Analyzing English Grammar: An Introduction to Feature Theory. California State University, Northridge

[66] Goldsmith, A. (2015a) Grammar: All you Need to Know 2nd Edition. UBRU Press

[67] Harmer, J. (2002) The Practice of English Language Teaching 3rd Edition. London: Longman.

[68] Hinnon, A. (2015) Common Errors in English Writing and Suggested Solutions of Thai University Students. มนุษยศาสตร์สังคมศาสตร์ 31 (2) พ.ค. - ส.ค. 57

[69] Iriskulov, A., T. (2006) Theoretical Grammar of English. Uzbek State World Languages University.

[70] Kongkerd, W. (2013) Teaching English in the Era of English Used as a Lingua Franca in Thailand. Bangkok University ปีที่ 33 ฉบับที่ 4 ตุลาคม-ธันวาคม 2556

[71] Lightbown P, Spada N (1999) How languages are learned. Oxford: Oxford University Press.

[72] Lodico M, Spaulding D, \& Voegtle K (2006) METHODS IN EDUCATIONAL RESEARCH. From Theory to Practice. John Wiley \& Sons

[73] Lulu Meilina Alfiyani (2013) An Analysis of Grammatical Errors in Writing among the Second Semester Students of English Department of Yogyakarta State University. Thesis of English language Education Faculty of Languages and Arts.

[74] MacDonald. and Lightbound. (2005) An analysis of interlanguage errors in synchronous/asynchronous intercultural communication exchanges. Ph.D. thesis, Universitat de Val’encia

[75] Na-ngam, S. (2005) Common grammatical errors in foundation English I written assignments of Prince of Songkla University students with high and low English entrance examination Scores. Research paper: Prince of Songkla University.

[76] Nujaree Sukasame, Asst. Prof. Dr. Sathaporn Kantho, Assoc. Prof. Dr. PenneeNarrot (2013) A study of errors in learning English Grammatical structures on Tense of MatthayomSuksa 4 Students of The Demonstration School, KhonKaen University. www.sciencedirect.com

[77] Olcer A. The Negative Aspect of the Grammar-Translation Method (GTM) in Language Teaching. 2014 https://www.academia.edu/32375069/The_Negative_Aspect_of_the_Grammar-

Translation_Method_GTM_in_Language_Teaching_in_2014_

[78] Onwuegbuzie, A Most Common Formal Grammatical Errors Committed by Authors. Journal of Educational Issues ISSN 2377-2263 2017, Vol. 3, No. 1

[79] Rodsawang,S, S. Writing Problems of EFL Learners in Higher Education: A Case Study of The Far Eastern University. 2017, ปีที่ 11 ฉบับที่ 1 มกราคม The Far Eastern University

[80] Sing, Y. Fundamental Research Methodology and Statistics. 2006, NEW AGE INTERNATIONAL (P) LIMITED

[81] Suvarnamani, S. A Study of Grammatical and Lexical Errors in Descriptive Writing of First Year Arts Students at Silpakorn University. Silpakorn University Journal of Social Sciences, Humanities, and Arts, 2017, Vol.17(2): 239-264,

[82] Ur, P. Grammar Practice Activities: a practical guide for teachers. 1988, Cambridge: Cambridge University Press.

[83] Wulandari, I. GRAMMATICAL ERRORS FOUND IN ARTICLES' ABSTRACTS OF INDONESIAN SCHOLARLY JOURNALS. JEELS, 2014, Volume 1, Number 1, November 